\title{
Reorganisation in Ottawa
}

\begin{abstract}
A long-awaited bill on governmental organisation of scientific activities was finally presented to the Canadian Parliament shortly before Christmas. David Spurgeon reports from Ottawa.
\end{abstract}

THE bill proposes the reorganisation of the federal granting councils which provide funds for university research, and makes other changes concerning the Science Council of Canada and the Defense Research Board. At the same time Hugh Faulkner, Minister of State for Science and Technology, responded to concerns of the community about falling financial support, and said consideration is being given by the government to providing increases in 1977-78 budgets to cover inflationary increases in the cost of doing research.

The granting council changes were recommended several years ago by the Senate's special committee on science policy (the Lamontagne committee) and changes were promised by the government in February, 1974. According to $\mathrm{Mr}$ Faulkner, the bill is "the culmination of a lengthy series of studies, reports, meetings, and debates on the subject of science policy ...".

The bill creates a Social Sciences and Humanities Research Counci!. leaving the Canada Council, which has supported both the arts and research in the social sciences and humanities, to deal entirely with the arts. Mr Faulkner said the reorganisation "reflects the growth in size and quality of the social sciences and humanities (in Canada) and the new perception of their importance to the attack on socioeconomic problems, to national sovereignty, and to our cultural development". The bill also creates a Natural Sciences and Engineering Research Council, which will remove from the National Research Council of Canada the function of granting funds for university research in these areas. The NRC will henceforth deal with its own laboratories, industrial R\&D support programmes, and a national programme of scientific and technical information. $\mathrm{Mr}$ Faulkner said the new council "recognises the need for a separate agency to support university research in these disciplines (natural sciences and engineering) and to foster improved dialogue between natural scientists and research engineers."

The Medical Research Council Act is amended under the new legislation to remove the restriction preventing its support of research in public health, but otherwise the council remains unchanged.

In order to advise and co-ordinate the work of all the granting bodies, $\mathrm{Mr}$ Faulkner will establish an Intercouncil Co-ordinating Committee, chaired by the Secretary of the Ministry of State for Science and Technology. The committee will include the presidents of the granting councils and will report to $\mathrm{Mr}$ Faulkner.

Although the criterion of excellence will continue to be the basis of university research support, additional funds will he provided to the councils for regional balance of scientific capability, national problems and support of inter-disciplinary research.

The Science Council's mandate is also restated in the legislation, to provide it with a greater national and public role. It has actually played such a role for years, but, according to the Minister. "the new mandate .. . will state clearly that the Council is to act as a source of public information and to provide advice on the profound effects developments in science and technology will continue to have on our way of life."

Amendments are also proposed to the NRC Act to give it flexibility to respond to national problems more readily when science and technology have a part to play. Provision has also been made to transfer the responsibility for Canadian Patents and Develonment Limited from the NRC to the Ministry of Industry, Trade and Commerce. This is supposed to make easier exploit-

Reaction to the bill was not uncritical. Bill Kempling, Progressive Conservative MP for HaltonWentworth, asked whether it was the first of several steps to eliminate the science ministry. $\mathrm{He}$ noted that MOSST can be cancclled at any time, without reference to Parliament, by an order in council. And he suggested that what the bill really does is increase the number of accounting, auditing and administrative personnel at a time when the government is talking about restraint in spending.

$\mathrm{Mr}$ Kempling noted that the intercouncil co-ordinating committee has no budgetary control and called it "another layer of bureaucracy." It would have been better to have set up an overall science foundation reporting to a full minister, with a number of divisions for different disciplines.

Cyril Symes, New Democratic MP from Sault Ste Marie, said it appears ation of inventions from government and university laboratories by industry. Thus the role of NRC is to change somewhat, with "less responsibility for the general development of science in Canada and more for using the demonstrated capability of its laboratories in tackling national problems."

- Towards the end of last year, the Lamontagne committee chairman, Senator Maurice Lamontagne, reported on progress to date in the committee's resurrected hearings, and the group resolved to go on and finish them in 1977. Senator Lamontagne said the current sessions have heard from 31 organisations and have accumulated about 1.300 pages of evidence. Six or seven more meetings are needed to conclude the hearings, which are concentrating on determining how many of the recommendations the committee made in 1972 73 have been followed by the government, and in what way. $\mathrm{Mr}$ Lamontagne noted that the current hearings have shown that many recommendations have been carried out, but that failure to follow some "is now producing what has been described to us as an acute crisis, endangering Canada's future capability in the whole field of scientific research, technological development and economic and social innovation." The two recommendations he noted had not been followed concerned the need to transfer older researchers to other jobs in the private and public sectors and the need for greater national expenditure on $R \& D$. If the present situation continues, he warned, "Canada may lose a whole new generation of researchers".

to him that whenever the Liberal government gets into trouble and has no real policy answers, "it carries out the old double shuffle; it reorganises parts of its bureaucracy with great fanfare to make it appear that it is doing something, whereas in actuality it is just shuffling the cards ...". Mr Symes suspected that the bill was a sop to the lobbying of the science community, which had shown concern about funding cutbacks.

Paul Yewchuck, Progressive Conservative MP from Athabacsa, was concerned about the chairmanship of the intercouncil committee: "I can think of no good reason for the minister wanting one of his bureaucrats chairing the . . committee, unless he thinks he can control the actions of that committee better if onc of his underlings is in charge of it ... I would rather see an active scientist taking this position." 